North Carolina: Color the Tar Heels Federal Red and State Blue

Charles Prysby ${ }^{1}$

The 2004 elections in North Carolina resembled those in 1996 and 2000 in many ways. The candidates changed in a number of races, and some of the outcomes were different, but nevertheless there was a fundamental similarity among these three election years. Republicans carried the state by comfortable margins in all three presidential elections, and they had an advantage in each of the congressional elections as well. Even so, Democrats won all three gubernatorial elections and maintained control of state government. Thus, North Carolina in 2004 was once again both red and blue, depending on whether one looked at federal or at state election results. Election results for 1996, 2000, and 2004 are summarized in Table 1.

Republican strength was clearly greatest in presidential elections, even in 2004, when the presence of North Carolina's Senator John Edwards as the Democratic vice-presidential candidate was thought by some observers to make North Carolina a potentially competitive state. Congressional elections displayed a Republican edge but were more competitive. Republicans won both the 1996 and 2004 U.S. Senate elections by narrow margins, and the U.S. House seats were divided only slightly in favor of the Republicans in both 2000 and 2004. Republican success in federal elections did not carry over to state elections. The best performance by a Republican gubernatorial candidate was in 2000, when Richard Vinroot won 46 percent of the vote. Democrats won most of the other council of state races in all three years, and they captured a majority of the seats in both houses of the state legislature each time, with the exception of the state house in 1996.

Differences between presidential and subpresidential races, or between federal and state elections, are well-known features of modern southern politics (Aistrup 1996; Aldrich 2000; Bullock 1988; Glaser 1996, 7-16). From this perspective, the North Carolina 2004 elections are not unusual. What is notable, however, is the ability of North Carolina Democrats to maintain their strength in state government at a time when Republicans were making substantial gains at this level in other southern states. For example, Republicans held only about 40 percent of the state legislative seats in the South in early 1997 but controlled around 50 percent of the seats in early

CHARLES PRYSBY is professor of political science at the University of North Carolina at Greensboro.

The American Review of Politics, Vol. 26, Summer, 2005: 185-201

(C)2005 The American Review of Politics 
Table 1. North Carolina Election Results in 1996, 2000, and 2004

\begin{tabular}{lrrrrrr}
\hline & \multicolumn{2}{c}{1996} & \multicolumn{2}{c}{2000} & \multicolumn{2}{c}{2004} \\
& Dem. & Rep. & Dem. & Rep. & Dem. & Rep. \\
\hline National Elections & & & & & & \\
$\quad$ Presidential vote & 44 & 49 & 43 & 56 & 44 & 56 \\
$\quad$ U.S. Senate vote & 46 & 53 & - & - & 47 & 52 \\
$\quad$ U.S. House seats won & 6 & 6 & 5 & 7 & 6 & 7 \\
State Elections & & & & & & \\
$\quad$ Gubernatorial vote & 56 & 43 & 52 & 46 & 56 & 44 \\
$\quad$ Council of State offices won & 10 & 0 & 9 & 1 & 7 & 3 \\
$\quad$ State Senate seats won & 29 & 21 & 35 & 15 & 29 & 21 \\
$\quad$ State House seats won & 59 & 61 & 62 & 58 & 63 & 57
\end{tabular}

Notes: Vote percentages are of the total vote. The Council of State offices include the governor, lieutenant governor, and eight other executive positions, all elected statewide. No U.S. Senate seat was up for election in 2000 .

Source: Computed by the author from data obtained from the North Carolina Board of Elections.

2005, an increase to which North Carolina contributed nothing. Moreover, Tar Heel Democrats remained highly competitive in state elections even though North Carolina holds its major state elections in presidential election years, something no other southern state does. Despite the advantage of a winning candidate at the top of the ticket, North Carolina Republicans have been unable to make significant gains at the state level in recent years. Given the different outcomes across election levels, it seems appropriate to discuss the presidential, congressional, and state elections separately.

\section{The Presidential Election}

When Democratic presidential nominee John Kerry selected Edwards as his running mate, there were early expectations that 2004 would produce a much closer presidential contest than the state had seen in both 1996 and 2000, when North Carolina was largely ignored by the candidates of both parties. Despite his limited political experience-one term as senatorEdwards was considered a strong vice-presidential candidate. He was the only Democrat to win a U.S. Senate seat in North Carolina since 1986, an accomplishment that involved defeating an incumbent. His decision not to seek reelection in 2004 but to instead run for the Democratic presidential nomination was initially considered by many observers to be a premature effort that would not go far, but he came in second in the Iowa caucuses, the first major delegate selection event. Although he finished only fourth in the next event, the New Hampshire primary, he ran well in the eight primaries 
held in February, winning South Carolina and placing second in six other states (FEC 2005a). By March 2, the "Super Tuesday" in which nine states held primaries, Edwards was clearly the main challenger to Kerry; Edwards finished second to Kerry in each of the nine states except Vermont, which Vermont Governor Howard Dean won (FEC 2005a).

Edwards was placed on the ticket primarily because Kerry believed that Edwards' populist "two Americas" message would play well in some key swing states, like Ohio, and that including a southern Democrat would make the ticket seem more moderate and more appealing to swing voters. Still, Democrats hoped that Edwards might also help to deliver North Carolina's fifteen electoral college votes to Kerry.

Early in the campaign, North Carolina was included in the list of states into which the Democratic presidential campaign intended to put resources. Republicans naturally responded with similar plans, hoping to score a symbolic victory of defeating the Democratic ticket in Edward's home state. Unlike the previous two elections, the candidates of both parties visited the state. Kerry made three appearances in North Carolina during August and September, rather remarkable considering that the state had gone Republican in the past five elections and by a wide margin in 2000. North Carolina voters were treated (they might not have used that word) to campaign ads from both sides. An early August poll had Bush with just a three-point lead (Bonner 2004a). By October, prospects for a Democratic victory seemed less likely. Two late September polls showed Bush comfortably ahead, by 6 to 9 percentage points (Bonner 2004b; Morrill 2004). Both campaigns decided to devote few resources to the state for the remainder of the campaign. Even John Edwards was not seen much in his home state in October.

Although North Carolina wound up not being a battleground state, there was a much stronger effort to get out the vote on the part of both parties, in part due to resources sent from the national parties and presidential campaigns. A well-financed Republican effort reached around one million voters through direct mailings, phoning, and canvassing (Mears 2005). Contacting began weeks before the election in order to get supporters to vote early. A final push in the last 72 hours contacted 250,000 registered voters (Mears 2005). Democrats operated with a smaller budget but were able to rely on a large volunteer force (Falmlen 2005). They also had a much stronger effort in 2004 than they did in 2000. For example, the Democratic combined campaign had 80 full-time staffers, more than double the number in 2000 (Falmlen 2005). African Americans and single women were both highly targeted Democratic groups. The result of all these efforts was a higher than usual turnout in the state: 58 percent of the eligible electorate voted, compared to 53 percent in 2000 (McDonald 2005). ${ }^{2}$ 
An insightful way of viewing the 2004 presidential election outcome is to compare it to the results for previous years and to benchmark North Carolina against the South and the nation. The relevant data are in Table 2. As can be seen, George Bush won almost exactly the same share of the twoparty vote in 2004 as he did in 2000, a fact that suggests that Edwards had a negligible impact on the race. However, when North Carolina is compared to the region and the nation, a somewhat different image emerges. While North Carolina was about one-percentage point more Republican than the South in 2000, it was about 1.5 points less Republican in 2004. Compared to the nation, North Carolina was 7.7 points more Republican in 2000 but only 4.8 points more Republican in 2004. Thus, we could infer that Edwards gave a boast to the ticket of between 2.5 and 3.0 points - not an overwhelming impact, but perhaps about what would normally be expected from a vicepresidential candidate, especially considering that Edwards did not campaign extensively in the state.

The sources of support for Bush and Kerry in 2004 were similar to the patterns that existed for the Bush-Gore 2000 race (for the 2000 exit poll data, see Prysby 2002). Table 3 presents the voting patterns for some basic demographic groups. Race clearly stands out as the most important factor. Blacks voted overwhelming for Kerry, although not quite as much as they did in 2000, when they gave 90 percent of their vote to Gore. Whites voted heavily for Bush in 2004, even more so than in 2000. Counteracting these pro-Republican trends were changes in the racial composition of the electorate. If the exit poll data are accurate, blacks accounted for about onefourth of the voters in 2004 versus about one-fifth in 2000. This substantial increase probably is best attributed to an improved get-out-the-vote effort on the part of the Democrats, an effort that always targets blacks first and foremost.

Table 2. North Carolina Election Results in 1996, 2000, and 2004

\begin{tabular}{lcccccc}
\hline Presidential Vote & 1984 & 1988 & 1992 & 1996 & 2000 & 2004 \\
\hline North Carolina & 62.0 & 58.2 & 50.5 & 52.5 & 56.5 & 56.2 \\
South & 62.6 & 58.8 & 49.9 & 50.0 & 55.5 & 57.6 \\
Nation & 59.2 & 53.9 & 46.5 & 45.4 & 48.8 & 51.4 \\
NC vs. South & -0.6 & -0.6 & +0.6 & +2.5 & +1.0 & -1.4 \\
NC vs. Nation & +2.8 & +4.3 & +4.0 & +7.1 & +7.7 & +4.8
\end{tabular}

Note: Entries are the Republican percentage of the two-party vote for president. The South is defined as the eleven states of the Confederacy. The last two rows give the difference between the Republican vote in N.C. and in the South and the nation, respectively.

Source: Computed from data in America Votes (various editions, as appropriate), the North Carolina Board of Elections Web site, and the National Archive Web site. 
Table 3. North Carolina Voting by Selected Demographic Variables, 2004

\begin{tabular}{|c|c|c|c|}
\hline Variable & $\begin{array}{l}\% \text { Voting } \\
\text { for Kerry }\end{array}$ & $\begin{array}{c}\% \text { Voting } \\
\text { for Bowles }\end{array}$ & $\begin{array}{l}\text { \% Voting } \\
\text { for Easley }\end{array}$ \\
\hline All Voters & 43 & 46 & 55 \\
\hline \multicolumn{4}{|l|}{ Race } \\
\hline White (71) & 27 & 30 & 43 \\
\hline Black (26) & 85 & 87 & 87 \\
\hline \multicolumn{4}{|l|}{ Gender } \\
\hline Male (41) & 38 & 41 & 51 \\
\hline Female (59) & 46 & 50 & 57 \\
\hline \multicolumn{4}{|l|}{ Income } \\
\hline Under $\$ 50,000(50)$ & 55 & 59 & 64 \\
\hline$\$ 50,000$ and over $(50)$ & 31 & 35 & 45 \\
\hline \multicolumn{4}{|l|}{ Education } \\
\hline No college education (26) & 50 & 54 & 62 \\
\hline Some college (29) & 39 & 44 & 53 \\
\hline College degree (45) & 43 & 46 & 53 \\
\hline \multicolumn{4}{|l|}{ Age } \\
\hline Under 30 (14) & 56 & 57 & 63 \\
\hline $30-59(63)$ & 39 & 44 & 52 \\
\hline 60 and older (22) & 43 & 46 & 56 \\
\hline \multicolumn{4}{|c|}{$\begin{array}{l}\text { Note: Entries are the percentage of voters in the specified category who voted for the Democratic } \\
\text { presidential, senatorial, and gubernatorial candidates (Kerry, Bowles, and Easley). The figures in } \\
\text { parentheses indicate the percentage of all respondents in that category. For example, the data for race } \\
\text { indicate that whites were } 71 \text { percent of the electorate in } 2004 \text { and that } 27 \text { percent of whites voted for } \\
\text { Kerry. Only the percentages for the Democratic candidates are shown; these were essentially two- } \\
\text { candidate races, so the proportion of the vote not going to the Democratic candidate went almost } \\
\text { entirely to the Republican candidate. } \\
\text { Source: National Election Pool } 2004 \text { North Carolina exit poll. }\end{array}$} \\
\hline
\end{tabular}

Differences along socio-economic lines also were strong in 2004, especially if we look at income. Voters with incomes above $\$ 50,000$ per year (about one-half of all voters) were almost 25 percentage points more Republican in their presidential vote than those below $\$ 50,000$, a substantially greater difference than existed in 2000. Differences by education are not nearly as great as those for income, but those without any college education were noticeably more Democratic than those with at least some college education, and again the 2004 patterns display a sharper class cleavage than what we find for 2000 . 
Finally, gender and age differences were present. The gender gap in 2004 was no greater than what it was in 2000, and it is similar to the national pattern, so there is nothing particularly notable here. Age differences are more interesting, however. The under-30 voters were much more supportive of Kerry, although they accounted for only about one voter in seven. This was a sharper age divide than existed in 2000 , and it reflects a national pattern. Kerry did well among younger voters, perhaps because they were less supportive of the war in Iraq. Moreover, Kerry did better among the under30 voters in North Carolina than he did nationally (56 to 54 percent), even though he ran worse among voters who were older. ${ }^{3}$ The result was a much stronger difference between age groups in North Carolina than in the nation, a pattern for which there is no clear explanation.

Table 4 presents voting by several political and religious orientations. Some extremely strong relationships are present. First of all, presidential voting was highly related to party identification. We expect a strong relationship between these two variables, but the connection in 2004 was particularly great. Almost all of the Republicans voted for Bush, and well over 80 percent of the Democrats voted for Kerry. Republicans and Democrats each accounted for about 40 percent of the electorate in 2004; in previous presidential elections, Democrats outnumbered Republicans (41 to 37 percent in 2000, for example). It is this shift in the composition of the electorate that explains why Bush did as well in North Carolina in 2004 as he did in 2000 , even though he ran slightly worse among Democrats and independents the second time around.

Ideological and religious orientations also were strongly related to the vote, which is not surprising since these attitudes are strongly related to party identification. Bush won over 80 percent of the vote of self-identified conservatives. He did equally well among whites who described themselves as evangelical or born-again, both highly conservative groups (Green et al. 2003).

The vote also reflected evaluations of the performance of the Bush administration as evidenced by the extremely strong relationship that the presidential vote had to approval of Bush's job performance and to approval of the decision to go to war in Iraq. Similarly strong relationships existed at the national level, so it appears that voting in North Carolina can be explained by the same factors that we would use nationally. Bush did very well among Republicans, conservatives, and those who approved of his performance as president - and party identification, ideology, and presidential job performance were interrelated to a much greater extent than in previous years. 
Table 4. North Carolina Voting by Selected Political and Religious Orientations, 2004

\begin{tabular}{|c|c|c|c|}
\hline Variable & $\begin{array}{l}\% \text { Voting } \\
\text { for Kerry }\end{array}$ & $\begin{array}{l}\% \text { Voting } \\
\text { for Bowles }\end{array}$ & $\begin{array}{l}\% \text { Voting } \\
\text { for Easley }\end{array}$ \\
\hline All Voters & 43 & 46 & 55 \\
\hline $\begin{array}{l}\text { Party identification } \\
\text { Democrats (39) } \\
\text { Independents (21) } \\
\text { Republicans (40) }\end{array}$ & $\begin{array}{r}84 \\
41 \\
4\end{array}$ & $\begin{array}{r}89 \\
47 \\
6\end{array}$ & $\begin{array}{l}90 \\
59 \\
19\end{array}$ \\
\hline $\begin{array}{l}\text { Ideology } \\
\text { Liberal (17) } \\
\text { Moderate (44) } \\
\text { Conservative (40) }\end{array}$ & $\begin{array}{l}80 \\
50 \\
18\end{array}$ & $\begin{array}{l}84 \\
55 \\
21\end{array}$ & $\begin{array}{l}83 \\
65 \\
31\end{array}$ \\
\hline $\begin{array}{c}\text { Religious orientation } \\
\text { White evangelical/ } \\
\text { born-again (36) } \\
\text { Other (64) }\end{array}$ & $\begin{array}{l}16 \\
58\end{array}$ & $\begin{array}{l}21 \\
60\end{array}$ & $\begin{array}{l}34 \\
64\end{array}$ \\
\hline $\begin{array}{l}\text { Bush job rating } \\
\text { Approve (57) } \\
\text { Disapprove (42) }\end{array}$ & $\begin{array}{r}6 \\
94\end{array}$ & $\begin{array}{l}14 \\
92\end{array}$ & $\begin{array}{l}29 \\
92\end{array}$ \\
\hline $\begin{array}{l}\text { Decision to go to wa } \\
\text { Approve (54) } \\
\text { Disapprove (42) }\end{array}$ & $\begin{array}{r}8 \\
89\end{array}$ & $\begin{array}{l}16 \\
88\end{array}$ & $\begin{array}{l}30 \\
89\end{array}$ \\
\hline \multicolumn{4}{|c|}{$\begin{array}{l}\text { Note: Entries are the percentage of voters in the specified category who voted for the } \\
\text { Democratic presidential, senatorial, and gubernatorial candidates (Kerry, Bowles, and } \\
\text { Easley). The figures in parentheses indicate the percentage of all respondents in that } \\
\text { category. For example, the data for party identification indicate that } 39 \text { percent of the } \\
\text { voters were Democrats in } 2004 \text { and that } 84 \text { percent of Democrats voted for Kerry. Only } \\
\text { the percentages for the Democratic candidates are shown; these were essentially two- } \\
\text { candidate races, so the proportion of the vote not going to the Democratic candidate went } \\
\text { almost entirely to the Republican candidate. } \\
\text { Source: National Election Pool } 2004 \text { North Carolina exit poll. }\end{array}$} \\
\hline
\end{tabular}

\section{Congressional Elections}

The most watched election in North Carolina in 2004 was the race between Erskine Bowles and Richard Burr for the U.S. Senate seat being vacated by Edwards. Recent senatorial races in the state had been very competitive. The last five such elections, held between 1990 and 2002, were decided by an average margin of victory of 4.5 percentage points. No winning candidate was able to win 55 percent of the two-party vote. Two of the 
elections involved the defeat of an incumbent. With this history and with an open seat, the expectation was for a very close election, particularly because both parties had strong and well-funded candidates.

The Democratic candidate, Bowles, ran and lost in the 2002 senatorial election, his first attempt at elected office (Prysby 2004). Despite that loss, Bowles was considered to have a good chance of winning in 2004. In 2002, he faced Elizabeth Dole, a candidate with great name recognition in the state. In 2004, he held the early advantage in name recognition. Also, the 2002 campaign was a fairly civil contest, in which Bowles ran a creditable campaign, so he emerged from his loss with a reasonably positive image (Prysby 2004). In 2002, Bowles had to first win a very competitive Democratic primary election, which forced him to begin his general election campaign quite late, as court challenges to the state legislative redistricting pushed the North Carolina primary elections from it usual May date to September (Prysby 2004). This was a significant disadvantage for Bowles, as he had limited time to overcome Dole's early advantage. In 2004, Bowles began immediately on his general election campaign, as he had no opposition for the nomination. Also, in 2004 Bowles had the experience of having run a statewide race. Thus, the expectation was that Bowles would be able to run a better campaign and would face a somewhat weaker opponent.

Of course, 2004 was a presidential election year, which might have put Bowles under a bigger disadvantage than in 2002, a midterm election. However, 2002 turned out to be an unusual midterm election, one in which the president's party nationally gained seats in Congress (Abramson, Aldrich, and Rohde 2003, 252-257). The midterm advantage that Bowles surely hoped for when he first decided to run in 2002 never materialized. Moreover, although 2004 was a presidential election year, which normally would be a significant advantage for a Republican senatorial candidate, the presence of Edwards on the Democratic ticket undoubtedly led Bowles to hope that, even if Bush carried the state, he would do so only narrowly, which would give only a slight boost to the Republican senatorial candidate.

Richard Burr, the Republican candidate, was a five-term congressman from the Fifth District, which includes Winston-Salem as its major city. Although well-known and highly regarded in his district, he lacked substantial statewide name recognition. Still, as a popular congressman who was sure to have a large campaign finance chest, he seemed to be a strong candidate, especially if Bush were able to carry the state by a substantial margin. Moreover, he had the strong support of the Bush administration, which both discouraged serious Republican opposition to his candidacy and ensured that he would have national help for his campaign. Interestingly, neither Bowles nor Burr faced a competitive primary, a normally unexpected situation for an open U.S. Senate seat in a state where previous senatorial elections had been highly competitive. 
Bowles ran what most observers considered to be a very well-run and well-financed campaign. He wisely presented himself as a moderate Democrat (Dyer 2004a, 2004b). In fact, Bowles downplayed his party affiliation, talking more about how he would be an independent thinker. He criticized Burr for supporting the president over 90 percent of the time, saying that if he were in the Senate, he would not support anyone so consistently. During the campaign, he stressed consensus issues, like improving the economy and stemming the job losses that North Carolina had recently experienced. Although he did not stress specific policy proposals in his campaign, his positions on economic issues were fairly liberal. He favored increased federal spending on education and health care, opposed privatization of social security, and supported pro-environmental actions (Bowles 2004).

Burr stressed his conservatism, his Republicanism, and his support for Bush in his campaign. He talked about the need to lower taxes and spending, the need to decrease governmental regulation, and the need to enact tort reform (Burr 2004). He also opposed abortion and gay marriage (Burr 2004). All of these positions were consistent with his record as a congressman. In 2002, he received high marks from two conservative/business-oriented organizations (a 96 percent rating from the American Conservative Union and a 92 percent rating from the Chamber of Commerce) and low marks from three liberal/environmentally-oriented organizations (a 13 percent rating from the American Civil Liberties Union, a 13 percent rating from the League of Conservation Voters, and a zero rating from the Americans for Democratic Action) (Barone and Cohen 2003, 1205). Still, Burr campaigned on the basis of some government programs that he sponsored, especially the tobacco-buyout legislation that passed Congress in 2004, which was a very popular bill in North Carolina. Also, like Bowles, Burr often talked about the need to improve the economy and to protect North Carolina workers from unfair foreign trade, positions that evoked no disagreement in the state.

Burr's campaign seemed unorganized at the beginning. In fact, in August and September, he frequently drove around the state by himself, stopping when and where he felt like doing so (in comparison to Bowles, who traveled on a tight schedule and with staff). After initial efforts to boost his name recognition, Burr went on the attack in late September with campaign ads that attacked Bowles for his ties to the Clinton administration (Bowles had served as chief-of-staff for Bill Clinton early in Clinton's second term) and for wanting to raise taxes (Dyer 2004c). Bowles responded with attacks on Burr. Both candidates spent heavily-about $\$ 13$ million each - with much of the money going to advertising (FEC 2005b). The last month of the campaign was highly negative in tone and not very informative for most voters. Accusations often focused on minor issues. For example, Bowles accused Burr for failing to support legislation that would have 
required medical insurers to cover treatment for breast cancer (Rice 2004a); Burr responded with ads attacking Bowles for running misleading ads on this issue (Skalski 2004). Trade was an important issue in a state that had lost many textile jobs to foreign competition in recent years, but the candidates did little to clarify their differences on this policy issue. Each said that the other was weak on trade and had supported NAFTA in the past. Some of the accusations were more personal in nature, such as when Bowles ran ads claiming that Burr had taken large amounts of special interest money (Rice 2004b). Unfavorable images of both candidates increased; by mid-October, both candidates were viewed unfavorably by more than one-third of the voters (Morrison 2004).

Burr's media campaign seemed to help him. An early September poll showed Bowles with a ten-point lead, but an early October poll had the race virtually even (Survey USA 2004). Burr later moved into the lead and won the election by five points. Burr ran somewhat behind Bush in the overall vote totals, but the voting patterns in the senate contest were very similar to those in the presidential race, both demographically and attitudinally, as we can see in Tables 3 and 4. Bowles ran extremely well among blacks, but only won about 30 percent of the vote of whites. Burr did much better among voters who had an above average income and better among those with some college education, patterns that nicely match those for the presidential contest. Gender and age were related to voting in very much the same way in both elections. Party identification and ideology were very strong determinants of the vote. Democrats and liberals provided very strong support for Bowles, Republicans and conservatives went heavily for Burr, and independents and moderates were very evenly divided. Finally, the vote for senator strongly reflected evaluations of presidential performance. Bowles's attempt to present himself as a moderate and independent Democrat did result in his doing better than Kerry did among moderates and conservatives, but the improvement was very slight. The fact that Bush won 56 percent of the vote most likely helped Burr, but it is uncertain whether a close presidential race would have changed the outcome of the senate election.

While the U.S. Senate election attracted considerable attention, the U.S. House races did not. This was largely because most of the races were considered to be uncompetitive, and none was considered to be a true toss-up. Basic information about these races is summarized in Table 5. In eleven of the thirteen contests, an incumbent was running for reelection (one was a very short-term incumbent, having been elected in July to fill the unexpired term of a resigning House member). Most of the incumbents had served at least four previous terms in Congress; only one was a freshman congressman. None had won his or her seat with less than 55 percent of the vote in 
Table 5. Congressional Election Outcomes in North Carolina, 2002-2004

\begin{tabular}{ccccl}
\hline Congressional & $\begin{array}{c}2000 \\
\text { Presidential } \\
\text { Election } \\
\text { District }\end{array}$ & $\begin{array}{c}2002 \\
\text { U.S. House } \\
\text { Election } \\
\text { (\% Repub.) }\end{array}$ & $\begin{array}{c}2004 \\
\text { U.S. House } \\
\text { Election } \\
(\% \text { Repub.) }\end{array}$ & $\begin{array}{l}\text { 2004 District Winner } \\
\text { (\# of previous terms) }\end{array}$ \\
\hline 1 & 42 & 35 & 36 & Butterfield \\
2 & 53 & 33 & 38 & Etheridge (4) \\
3 & 64 & 100 & 71 & Jones (5) \\
4 & 46 & 37 & 36 & Price (8) \\
5 & 66 & 70 & 59 & Foxx \\
6 & 67 & 100 & 73 & Coble (10) \\
7 & 52 & 28 & 27 & McIntyre (4) \\
8 & 54 & 55 & 56 & Hayes (3) \\
9 & 63 & 73 & 70 & Myrick (5) \\
10 & 65 & 61 & 64 & McHenry \\
11 & 58 & 57 & 55 & Taylor (7) \\
12 & 42 & 34 & 33 & Watt (6) \\
13 & 50 & 43 & 41 & Miller (1)
\end{tabular}

Notes: Entries under election results are the Republican percentage of the two-party vote. The figures for the 2000 presidential election are the vote percentages calculated on the basis of the 2002 district boundaries. Butterfield is listed as not having served any previous terms, but he was a shortterm incumbent, having been elected in a special election in July, 2004, to replace the incumbent, who resigned from office. Price is listed as having eight previous terms, but these were not all consecutive; he served four terms, was defeated in 1994, and then elected again from 1996 on.

Source: Calculated from data provided by the North Carolina Board of Elections Web site and from data in The Almanac of American Politics 2004.

2002. All of these facts would normally suggest little basis for intense competition in 2004. The lack of competition in most districts is in large part a result of the way that the district lines were drawn. While the two parties split the thirteen districts very evenly (Republicans won seven of the seats), no individual race was highly competitive.

Table 5 shows the 2000 presidential vote for each of the districts, which is a good indication of the underlying partisanship of the district. Three of the districts (the First, Fourth, and Twelfth) seem safely Democratic; in each of these districts, Gore received at least 54 percent of the vote in 2000. Six districts probably are safely Republican (the Third, Fifth, Sixth, Ninth, and Eleventh), as evidenced by the fact that Bush won 58 percent or more of the vote in each of them. In the remaining four districts, Bush won between 50 and 54 percent of the vote. These can be considered potentially competitive. Democrats won three of these four districts. In the Thirteenth District, which clearly leans Democratic, Brad Miller was reelected to his second term with nearly 60 percent of the vote. This district might be placed in the safely 
Democratic column in 2006 if Miller runs for reelection again. In the Second and Seventh districts, Democrats Bob Etheridge and Mike McIntyre easily won reelection; both are congressmen who have presented themselves as moderate Democrats in tune with the values of their constituents. These districts probably would be competitive as open seats, but the current incumbents are becoming entrenched. Finally, in the Eighth District, Republican Robin Hayes has been identified as vulnerable each time that he has sought reelection, but he somehow has avoided facing a really strong challenger. In 2004 , for example, his opponent spent only $\$ 225,000$ to Hayes's \$1.6 million (FEC 2005b).

These results suggest that there are enough potentially competitive seats that future elections could result in either party gaining a seat or two, but in the absence of strong national forces (such as we saw in 1994), seat changes may occur only when incumbents retire or when an incumbent is vulnerable because of some particular problem, such as a personal scandal. Strong and well-financed challengers seem very reluctant to come forward and provide incumbents with real competition. This is a great change from the 1980s, when many congressional races in the state were very close and a number of incumbents were defeated. The changing pattern of competition in North Carolina reflects a national trend toward more safe seats. In 2004, only 35 of the 435 seats in the House of Representatives were considered highly competitive by Congressional Quarterly (Harrell 2004).

\section{State Elections}

In 2000, Mike Easley, then state attorney general, won the gubernatorial election. He did so despite facing a strong Republican candidate in a year in which Bush carried the state by a wide margin. Still, many Republicans viewed Easley as beatable in 2004. The state economy struggled during the first Easley administration as job losses in the manufacturing sector, particularly in the textile industry, led to increases in the unemployment rate. A sluggish economy produced budget problems for the state. Easley responded by supporting both budget cuts and tax increases. Republicans accused Easley of poorly handling the economic and budget problems facing the state.

A number of Republicans sought their party's gubernatorial nomination, including Richard Vinroot (who lost to Easley in 2000), Bill Cobey (a former congressman and former state party chair), and Patrick Ballantine (the minority leader in the state senate). Ballantine led in the first primary but with only 30 percent of the vote, far short of the 40 percent needed for outright victory. The second place finisher, Vinroot, could have requested a runoff primary, but he decided not to do so. The defeated candidates closed 
ranks behind Ballantine. Even with this unity, Ballantine faced difficult challenges. He lacked statewide name recognition. He also was unable to match Easley in fund raising-Ballantine spent $\$ 4.5$ million compared to over $\$ 8$ million for Easley (Board of Elections 2005a, 2005b). Finally, as governor, Easley was able to travel around the state and talk about what had been accomplished during his first term (Ingram 2004a).

Easley carefully presented himself as a moderate Democrat. He was not present at any of the Kerry-Edwards campaign events. He did not take liberal positions on most social issues. He supported the death penalty, opposed allowing gays to marry, and avoided taking a position on abortion, for example. He emphasized his attempts to improve education and the economy, both largely noncontroversial goals. While he supported increased education spending, he also argued that he was fiscally prudent. One of Easley's pet proposals was for a state lottery with the revenue earmarked for education, a way of increasing education funding without raising taxes (Ingram 2004b). Easley's conservatism, at least for a Democrat, was reflected in two interesting endorsements. First, the North Carolina Black Leadership Caucus declined to endorse Easley (Associated Press 2004b). Second, the state employee's association endorsed Ballantine, who promised to support a 5 percent pay raise for state employees (Associated Press 2004a).

Ballantine accused Easley of mishandling the budget problems facing the state. One Ballantine ad accused Easley of raising a wide range of taxes (Dyer 2004d). Easley responded to Ballantine's charges about the budget by arguing that Ballantine would not be able to balance the budget, a charge that may have resonated with many voters since Ballantine ruled out any tax increases yet also supported a substantial pay raise for state employees (Dyer 2004e). Easley also responded to Ballantine's criticisms of the state's educational system by arguing that the state was making progress on test scores (Ingram 2004b). Ballantine's criticisms of Easley's economic policies probably did not convince many voters either. Since the downturn in the state's economy reflected national economic conditions, it was difficult to blame the governor for poor economic growth. Similarly, job losses in the textile industry were widely attributed to foreign competition (both U.S. Senate candidates were making this argument), another problem that voters were unlikely to blame the governor for. In general, Ballantine was unable to develop a strong line of attack on Easley's first term performance. Thus, it is not surprising that Easley had little difficulty in being reelected.

Voting patterns for governor were somewhat different than the patterns for president or senator (see Tables 3 and 4). These differences suggest why Easley was able to win even though Republicans won the presidential and senatorial races. The comparison of the vote for Easley and Bowles is 
particularly revealing. Easley did no better than Bowles among liberals and Democrats, but he did significantly better among other voters. He won decisive majorities of the vote of independents and moderates and even attracted nearly one-fifth of the vote of Republicans and nearly one-third of the vote of conservatives, far better showings than Bowles was able to register among these voters. Easley's ability to attract moderate and conservative voters led to his winning 43 percent of the white vote (Bowles won only 30 percent). In North Carolina, as in the rest of the South, Democratic success depends on the ability to forge a biracial coalition. The usual rule of thumb in North Carolina is that a Democrat must capture about 40 percent of the white vote to win election, so the difference between Easley and Bowles on this dimension is telling.

Both Easley and Bowles attempted to present themselves as moderate Democrats, as was previously discussed, but Easley was more successful in doing so. Easley's success in this regard probably resulted from several factors. First, Easley was fairly conservative on social issues, something that was pointed out above, which is reflected in the fact that he won a third of the vote of white evangelical voters. Also, Bowles was linked to the Clinton administration (and the Burr ads were not bashful about reminding voters of this fact), which may have undercut his attempts to appeal to moderate and conservative voters. Moreover, the senatorial election was more directly related to the presidential election. Voters were likely to base their vote for U.S. Senator in part on whether they wanted someone in Congress who would support the policies of President Bush. The gubernatorial election revolved around somewhat different issues, a natural difference between federal and state elections. For example, spending on education was a prominent issue in the gubernatorial election but not in the senatorial election. Thus, when Ballantine criticized Easley for supporting higher taxes during his first term, Easley was able to turn that line of attack back on Ballantine, accusing him of unrealistically arguing that the state could lower taxes and improve education at the same time. The fact that Ballantine opposed Easley's proposed education lottery reinforced this point.

Besides governor, North Carolina elects nine other statewide executive offices. Republicans were able to capture three of these nine offices in 2004, their highest total ever.

State legislative elections resulted in a narrow but clear victory for the Democrats. Following the 2002 elections, the lower house of the state legislature was evenly divided. To resolve this deadlock, a minority of Republicans joined with the Democrats to support a co-speakership arrangement with Democrat Jim Black and Republican Richard Morgan sharing the speakership. The majority of Republicans attacked Morgan and his allies as traitors. This disunity among Republicans seems not to have advantaged 
them. In 2004, Democrats were able to secure a narrow majority of the seats in the house and to expand their existing majority in the state senate. Combined with Easley's victory, the state legislative election results indicate that Democrats remain very competitive at the state government level.

Looking forward to 2008, when Easley will be ineligible to run again for governor, there are several fairly prominent Democrats who are potential candidates, such as Secretary of State Elaine Marshall or Attorney General Roy Cooper. Republicans lack an officeholder with the same stature and experience. The ability of Democrats to gain legislative seats probably will encourage Democrats in subsequent state legislative races. Still, while the immediate future appears promising for Democrats, a shift toward the Republicans of just a few percentage points could shift control of state government. Thus, we should not rule out the possibility that Republicans will control one or both houses of the state legislature and/or the chief executive in the near future.

\section{Conclusion}

Democrats in North Carolina remained in about the same situation following the 2004 elections as they were in after the 1996 and 2000 elections - uncompetitive in the presidential election, competitive but in the minority for congressional elections, and in the majority for state elections. The stability of election results over the past three presidential elections may suggest that Republican advancement within the state has reached a plateau and that the party system is at an equilibrium level. However, in the past there were periods of Republican growth that were followed by periods of stagnation and then by more growth. Thus, it is unclear whether the state will remain in its current highly competitive state or whether it will drift more toward the Republicans in the near future. Both parties had encouraging successes in 2004, depending on whether we look at federal or state elections. The conflicting results of the last election suggest that both parties have reason for optimism about their prospects in future elections.

\section{NOTES}

\footnotetext{
${ }^{1}$ Benjamin Anderson, an undergraduate political science major at UNCG, helped to collect the data for this article.

${ }^{2}$ These turnout figures are based on the voter eligible population (VEP), not the voting age population (VAP), which is often used as the base for computing turnout figures. The voter eligible population excludes non-citizens and felons who are ineligible to vote. For a discussion of the VEP versus the VAP, see McDonald (2005).

${ }^{3}$ In North Carolina, Kerry won 39 percent of the vote from those who were 30 to 59 years old and 43 percent of the vote from those who were 60 or over in age. Nationally,
} 
Kerry won 47 percent of the 30 to 59 year old group and 46 percent of the 60 and over group.

\section{REFERENCES}

Abramson, Paul R., John H. Aldrich, and David W. Rohde. 2003. Change and Continuity in the 2000 and 2002 Elections. Washington, DC: CQ Press.

Aistrup, Joseph A. 1996. The Southern Strategy Revisited: Republican Top-Down Advancement in the South. Lexington, KY: University Press of Kentucky.

Aldrich, John H. 2000. Southern Parties in State and Nation. Journal of Politics 62:643670.

Associated Press. 2004a. Workers Question Ballantine's Plans. Greensboro News and Record, September 11.

Associated Press. 2004b. Black Political Groups Won't Endorse Easley. Greensboro News and Record, October 29.

Barone, Micheal, and Richard E. Cohen. 2003. The Almanac of American Politics 2004. Washington, DC: National Journal Group.

Board of Elections. 2005a. Campaign Finance Results for the Mike Easley Committee: Fourth Quarter Disclosure Report. North Carolina State Board of Elections Website (accessed on February 7, 2005, at http://www.sboe.state.nc.us/index.html).

Board of Elections. 2005b. Campaign Finance Results for Ballantine for Governor Comittee: Fourth Quarter Report. North Carolina State Board of Elections Website (accessed on February 7, 2005, at http://www.sboe.state.nc.us/index.html).

Bonner, Lynn. 2004a. Bush, Kerry Close in N.C., Poll Says. Raleigh News and Observer, August 14.

Bonner, Lynn. 2004b. Bush Lead Grows in N.C. Raleigh News and Observer, September 28.

Bowles, Erskine. 2004. Erskine Bowles for Senate Website (accessed on September 22, 2005, at http://www.bowles2004.com).

Burr, Richard. 2004. Richard Burr for Senate Website (accessed on 22 September, 2004, at http://www.richardburrcommittee.com).

Bullock, Charles S. III. 1988. Regional Realignment from an Officeholding Perspective. Journal of Politics 50:553-574.

Dyer, Eric. 2004a. Bowles Sells His Independence in Senate Race. Greensboro News and Record, March 15.

Dyer, Eric. 2004b. In Senate Race, Bowles Runs Centrist Campaign. Greensboro News and Record, September 12.

Dyer, Eric. 2004c. Rivals for Senate Seat Trade Jabs. Greensboro News and Record, September 28.

Dyer, Eric. 2004d. Ad Watch. Greensboro News and Record, October 7.

Dyer, Eric. 2004e. Last Debate Heats Up Quickly. Greensboro News and Record, October 16.

Falmlen, Scott. 2004. Personal Interview with Scott Falmlen, Executive Director of the North Carolina Democratic Party, December 17. Raleigh, North Carolina.

Federal Election Commission (FEC). 2005a. 2004 Presidential Primary Election Results. FEC Website (accessed on 3 February at http://www.fec.gov/pubrec/fe2004/ 2004presprim.shtml). 
Federal Election Commission (FEC). 2005b. Summary Campaign Finance Reports. FEC Website (accessed on 8 February at http://www.fec.gov/finance/disclosure/ srsses.shtml).

Glaser, James M. 1996. Race, Campaign Politics, and the Realignment in the South. New Haven, CT: Yale University Press.

Green, John C., Lyman A. Kellstedt, Corwin E. Smidt, and James L. Guth. 2003. Conclusion: The Soul of the South: Religion and Southern Politics at the Millennium. In The New Politics of the Old South, 2nd. ed. eds. Charles S. Bullock III and Mark J. Rozell. Lanham, MD: Rowman and Littlefield.

Harrell, Peter E. 2004. The House: Dearth of Close Races Makes Status Quo a Best Bet. CQ Weekly, October 23.

Ingram, David. 2004a. Easley Would Win an Election Held Today. Winston-Salem Journal, October 2.

Ingram, David. 2004b. Candidates Attack Each Other's Education Votes. Winston-Salem Journal, October 5.

McDonald, Michael P. 2005. 2004 Voting-age and Voting-eligible Population Estimates and Voter Turnout. United States Election Project Website (accessed on February 7, 2005, at http://election.gmu.edu/Voter Turnout 2004.htm).

Mears, Christopher. 2004. Personal Interview with Christopher Mears, Political Director of the North Carolina Republican Party. December 17. Raleigh, North Carolina.

Morrill, Jim. 2004. Bush Campaign: N.C. All But Won. The Charlotte Observer, October 2 .

Morrison, Clarke. 2004. Burr, Bowles Neck and Neck for U.S. Senate Seat in Poll. Asheville Citizen-Times, October 21.

Prysby, Charles. 2002. North Carolina: Continued Two-Party Competition. In The 2000 Presidential Election in the South: Partisanship and Southern Party Systems in the 21st Century, eds. Robert P. Steed and Laurence W. Moreland. Westport, CT: Praeger.

Prysby, Charles. 2004. A Civil Campaign in a Competitive State: The 2002 North Carolina U.S. Senate Election. In Running on Empty? Political Discourse in Congresional Elections, eds. L. Sandy Maisel and Darrell M. West. Lanham, MD: Rowman and Littlefield.

Rice, David. 2004a. Bowles, Burr Ad Battle Heats Up. Winston-Salem Journal, October 22.

Rice, David. 2004b. New Bowles Ads Go On TV. Winston-Salem Journal, October 26.

Skalski, Ginny. 2004. Burr to Air New Ad Today. Durham Herald-Sun, October 28.

Survey USA. 2004. Survey USA Poll Report. Research conducted for WBTV-TV Charlotte and WTVD-TV Raleigh-Durham, October 5. 
